\title{
PROBLEMS WITH ASSESSING SAFETY OF VULNERABLE ROAD USERS BASED ON TRAFFIC ACCIDENT DATA
}

\section{P. OLSZEWSKI ${ }^{1}$, B. OSIŃSKA ${ }^{2}$, P. SZAGALA ${ }^{3}$, P. SKOCZYNSSKI $^{4}$, A. ZIELIŃSKA ${ }^{5}$}

\begin{abstract}
The problem of poor quality of traffic accident data assembled in national databases has been addressed in European project InDeV. Vulnerable road users (pedestrians, cyclists, motorcyclists and moped riders) are especially affected by underreporting of accidents and misreporting of injury severity. Analyses of data from the European CARE database shows differences between countries in accident number trends as well as in fatality and injury rates which are difficult to explain. A survey of InDeV project partners from 7 EU countries helped to identify differences in their countries in accident and injury definitions as well as in reporting and data checking procedures. Measures to improve the quality of accident data are proposed such as including pedestrian falls in accident statistics, precisely defining minimum injury and combining police accident records with hospital data.
\end{abstract}

Keywords: road safety, vulnerable road users, accident data quality, CARE database, accident statistics

\section{INTRODUCTION}

Assessments of road safety based on records of traffic accidents have been conducted for many years. These studies aim to provide a diagnosis of the road safety situation of an area or the whole country.

\footnotetext{
${ }^{1}$ Warsaw University of Technology, Faculty of Civil Engineering, Al. Armii Ludowej 16, 00-637 Warsaw, Poland, e-mail: p.olszewski@il.pw.edu.pl

${ }^{2}$ Warsaw University of Technology, Faculty of Civil Engineering, Al. Armii Ludowej 16, 00-637 Warsaw, Poland, e-mail: b.osinska@gmail.com

${ }^{3}$ Warsaw University of Technology, Faculty of Civil Engineering, Al. Armii Ludowej 16, 00-637 Warsaw, Poland, e-mail: p.szagala@il.pw.edu.pl

${ }^{4}$ Motor Transport Institute, ul. Jagiellońska 80, 03-301 Warsaw, Poland, e-mail: przemyslaw.skoczynski@its.waw.pl

${ }^{5}$ Motor Transport Institute, ul. Jagiellońska 80, 03-301 Warsaw, Poland, e-mail: anna.zielinska@its.waw.pl
} 
They are also used for benchmarking or comparing the safety situation between countries. In most countries, reports produced in such studies are routinely prepared by road authorities or the police, typically every year. They provide an overview of the road safety situation in the area under consideration using descriptive statistics. The reports also identify time trends and specific problems, such as the situation of vulnerable road users (VRU). However, the results of these studies are biased due to the well-known problems with police accident data, namely underreporting and inaccurate injury severity classification (see e.g. [10]). Despite that, traffic accident statistics give a good indication of the road safety situation and should form the basis of any safety assessment.

The problems of assessing road safety of VRUs using accident data have been examined by the authors within European research project InDeV (In-Depth understanding of accident causation for Vulnerable road users). One of the aims of the project was to determine the gaps in the existing databases and to propose possible measures to improve the quality of accident data. It is hoped that this will help to explain some inconsistencies in fatality and injury numbers in different countries and to enhance our ability to formulate appropriate policies and programmes for improving VRU safety. This paper presents the results of the first part of project InDeV [21] and is organised as follows: section 2 presents literature review on issues related to accident data quality; section 3 provides an overview of international databases; section 4 contains statistics of VRU accidents in the European Union (EU) countries to highlight problems with data quality; section 5 presents results of the survey conducted among partners of project $\mathrm{InDeV}$ and section 6 shows conclusions.

\section{Problems With aCCIDent data QUality}

\subsection{TYPES OF DATA PROBLEMS}

It is a basic fact that high-quality information on road accidents, fatalities and injuries is a prerequisite for safety assessment and the development of effective safety improvement programmes. Yet the quality of accident data poses multiple problems which have been reported and analysed in many studies e.g. [5], [24], [25]. Virtually every country or territory collects data on road accidents from reports recorded by the police. Over the years, the systems of data collection and processing have developed in each country independently and hence the major differences between these systems. According to a report on the SAU project [5], the differences in the numbers and types of accidents included in different databases stem from the differences in the following aspects:

- Traffic accident definitions assumed by the national/local administration, 
- Normative criteria used for including accidents in the database and classifying them by type,

- Real practice of the persons in charge of data recording and processing.

The three issues listed above contribute to the following problems with data quality and reliability in national road accident databases:

- Underreporting of accidents by the police,

- Misclassification of injury severity,

- Inaccurate or erroneous data,

- Incomplete or missing data.

In its document [9], the European Commission (EC) states that the total number of people seriously injured in road traffic is likely to be substantially higher than currently reported. The reason for this is that transport accident databases lack relevant and comparable data on serious injuries. There are two main problems: the lack of common definitions and the widespread underreporting and misreporting. In road safety data, the severity of an injury is sometimes defined on the basis of medical classifications and sometimes in terms of the long-term effects of the injury. Often, it is defined by the actual length of hospital stay.

In-depth accidents investigations [12] are very useful methods to supplement the missing data in national databases gathered by the police. The newest example of this type of analysis is the Study on Serious Road Traffic Injuries in the EU [1].

\subsection{DEFINITION OF A ROAD ACCIDENT}

The definition of an Injury Road Accident that has commonly been adopted in Europe [8] is that it is an incident on a public road that involves at least one moving vehicle and at least one casualty (person injured or killed). Thus, property damage only crashes are not considered "accidents" and in some countries are not recorded by the police. However, there is no clear definition of what constitutes an "injury" - the local criteria and practice may differ on whether minor scratches and bruises classify as an injury or not.

Luoma and Sivak [18] compared fatal road accident databases from 20 countries. Although the 30day fatality definition is commonly used, other criteria for the inclusion of fatalities in the database differ from country to country. For example, accidents on private roads that are open to the public are included in some but not all countries. Similarly, fatalities due to suicide or disease may or may not be included. The inclusion of accidents with trains, trams and animal-drawn vehicles also varies among different countries. Ever since the definition of a fatal road accident was adopted by the 
Vienna Convention in $1968^{6}$, efforts have been made to harmonise the definitions and criteria used to classify accidents and injury severity. This task became more urgent with the creation of an international road accident databases which combine data from many countries. As noted in a World Health Organisation (WHO) report [25], significant progress has been made: 92 countries (out of 182 ) used the 30-day fatality definition in 2011. However, there are still major differences in how the numbers of injured accident victims are calculated and classified.

Does the commonly adopted CARE (Community database on Accidents on the Roads in Europe definition) [8] of a road accident include all VRU accidents? Figure 1 shows the possible combinations of road users involved in an accident in the form of a collision matrix. The last row represents single-user accidents. VRU accidents are shown in green and cases consistent with the CARE definition are within the red frame. The definition requires that at least one moving vehicle should be involved in an accident so all combinations are covered except for single pedestrian accidents. These additional accidents (pedestrian falls) can be included in VRU safety assessment and economic evaluation. The other two conditions, i.e. location on a public road and at least one injured person should still be applied. A broad definition of public roads can also be used to include private roads open to the public.

Colliding road users

\begin{tabular}{|c|c|c|c|c|}
\hline & $\begin{array}{c}\text { Motor vehicle } \\
\text { 4+ wheels }\end{array}$ & $\begin{array}{c}\text { Powered two } \\
\text { wheeler }\end{array}$ & Bicycle & Pedestrian \\
\hline $\begin{array}{c}\text { Motor vehicle } \\
\text { 4+ wheels }\end{array}$ & & \multicolumn{3}{|l}{} \\
\hline $\begin{array}{c}\text { Powered two } \\
\text { wheeler }\end{array}$ & & & & \\
\hline Bicycle & & & & \\
\hline Pedestrian & & & & 㫥 \\
\hline $\begin{array}{c}\text { Single user } \\
\text { accident }\end{array}$ & & & \\
\hline
\end{tabular}

Legend

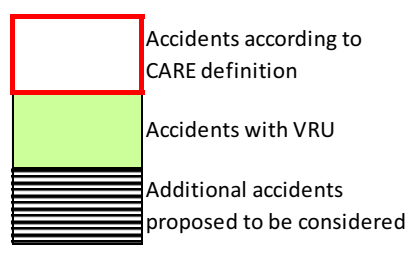

Fig. 1 Road user collision matrix

\footnotetext{
${ }^{6}$ A road fatality is any person killed immediately or dying within 30 days as a result of a road traffic accident.
} 


\subsection{UNDERREPORTING}

All three problems listed in section 2.1 contribute to the underreporting of accidents by the police. Misreporting and underreporting are largely due to the fact that in most EU countries, the national road traffic injury databases are based only on police reports [9]. However, the police are not called to every traffic accident and cannot be expected to perform a medical assessment; their diagnosis is only a rough on-the-spot estimate. This initial assessment by the police is not always checked against subsequent medical reports about injury severity. The serious problem of underreporting, especially among cyclists has been mentioned in many studies, e.g. [15], [17].

Alsop and Langley [2] examined police reporting rates of motor vehicle accident victims in New Zealand. They concluded that less than two-thirds of hospitalised accident victims were recorded by the police and that the reporting rate was higher for car occupants than for motorcyclists. The authors also found that the reporting rate was positively correlated with injury severity as measured by the AIS score. In a similar study in France [3] which was based on a large sample of almost 60 thousand road accident casualties, the average reporting rate was only $38 \%$. The study confirmed that underreporting varied with injury severity and road user type. Cyclist victims have the lowest probability of being police-reported, followed by pedestrians and motorcyclists. Thus, it can be concluded that police records are generally biased against VRU victims.

Because of the incompleteness of police databases, the records collected by the police are being combined with hospital records in some countries, e.g. in Sweden (the STRADA system). The results of a German study on bicycle accidents [14] confirmed the need for this approach. The number of bicycle accidents in Münster, where bicycle is the main transport mode, was nearly two times higher after the police accident database was combined with hospital data.

An international study [22] looked at the frequency of single-bicycle accidents in different countries. It was found that an average of $17 \%$ (between $5 \%$ and $30 \%$ ) of cyclist fatalities are caused by singleuser accidents. However, among the cyclist victims admitted to hospitals or treated in emergency departments, most (between $60 \%$ and $95 \%$ ) are the result of single-bicycle crashes.

\subsection{INCOMPLETE AND INACCURATE DATA}

Several epidemiological studies associated with VRU safety, e.g. [23], [6], [19], pointed to the limitations of large accident databases maintained by the police, which usually do not contain important information, such as the speeds of the colliding vehicles and the exact location of the accident. 
Another problem indicated by Chung and Chang [6] is the possibility of human error when police officers complete accident reports at the site of the accident and transfer the data to the electronic database. Several studies have been conducted in relation to this problem [4], [6], [7], [16]. Most errors in police reports occur when filling in information about accident location [16]. According to [6], the use of vehicle black boxes (VBB) in accident data collection has great potential to enrich police records and provide information such as time, the GIS-based location of the accident and vehicle speed.

A study by Tsui et al. ( cited in [17]) examined the issue of classification of injury severity in traffic accidents in Hong Kong. The study concluded that only 5.15\% (36 out of 699 cases) of serious accidents among cyclists are properly classified by the police. Some injuries are reported as serious although they are really not and vice versa. Another study [11] has indicated that only around 70\% of all serious injuries are actually reported.

\section{INTERNATIONAL ACCIDENT DATA SOURCES}

Community database on Accidents on the Roads in Europe (CARE) is a European road accident database hosted by the European Commission. The major difference between CARE and most other existing international databases is the high level of data disaggregation. All EU countries are obligated to provide information about road accidents to the European centralised database. The following classes of information are collected [8]: road user type (driver, passenger, pedestrian), gender, age group, vehicle group, area type, motorway, junctions, accident type, lighting conditions, weather conditions, time of accident. Not all of the data categories are provided by all countries. In most EU countries there is a lack of detailed information about the collision type (manoeuvres), there are also different subcategories of junction type.

CARE was created with the goal of harmonising accident information across Europe to make international comparisons more meaningful and to enable accurate benchmarking. Because of the disparate definitions in the CARE database and in national databases, EU countries apply transformation rules to harmonise the data. Despite that, differences remain regarding data quality, resulting in the incomparability of national datasets. For example, the definition criteria used to classify injury severity vary from country to country and only fatalities can be used with confidence in safety analyses when comparing the situation in EU countries. The CARE definitions are presented below [8]: 
- Injury Road Accident - incident on a public road involving at least one moving vehicle and at least one casualty (person injured or killed);

- Fatally injured - death within 30 days of the road accident, confirmed suicide and natural death are not included;

- Injured - the road user was seriously or slightly injured (but not killed) in the road accident;

- Seriously injured - injured (although not killed) in the road accident and hospitalized for at least 24 hours;

- Slightly injured - injured (although not killed) in the road accident and hospitalized less than 24 hours or not hospitalized;

- Not injured - person participating in the accident although not injured.

The Common Accident Dataset (CADaS) was developed to provide a common framework for road crash data collection in Europe. The implementation of this common dataset should help countries to improve and standardise their own road accident databases [26]. The scope of the CARE database (variables and values) should enable detailed road accident analysis at the EU level. However, national accident data collection systems use the $\mathrm{CADaS}$ format on a voluntary basis. There are a lot of differences between the national databases and some values and variables may not be compatible with the CADaS format. Data transformations are very often difficult, which explains why many entries in the CARE database are currently classified as "not available" or "others". The level of detail of the variables and values in CARE corresponds to all data that is useful for macroscopic data analysis and not for the detailed reconstruction of the scene of the accident, which is of local interest. The International Road Traffic and Accident Database (IRTAD) collects and aggregates international data on road crashes. It thereby provides an empirical basis for international comparisons and more effective road safety policies. The IRTAD includes safety and traffic/exposure data from 32 countries, aggregated by country and year from 1970 to present. All data are collected directly from relevant national data providers in the IRTAD countries. It is provided in a common format, based on the definitions developed and agreed by the IRTAD Group. The IRTAD database is aggregated and enables the analysis of trends in VRU accidents by type of road user, gender and age. However, it is impossible to perform accident causation analyses.

The World Health Organisation "Global status report on road safety 2013" [25] presents information on road safety from 182 countries. The methodology used to generate the data and information presented in that report involved the collection of data from each country, which was coordinated by a National Data Coordinator. The report presents only an overall view of road accident fatalities and the collected data are not sufficient for VRU safety analysis. 


\section{SAFETY OF VULNERABLE ROAD USERS IN SELECTED EU COUNTRIES}

As part of the InDeV project, statistical analyses of accident data were carried out with the aim of determining the scale of VRU safety problems and identifying typical locations and situations where most VRU accidents. This was done with respect to different VRU user groups: pedestrians, cyclists, motorcyclists and moped riders. The analysis was based on data from the CARE database and covered the seven InDeV partner countries: Belgium, Denmark, Germany, the Netherlands, Poland, Spain and Sweden as well as the whole European Union (EU28). Data from the five-year period 2009-2013 were analysed (2013 was the latest year for which all the data were available in CARE).

Accident data for all EU28 countries show a decreasing trend in the numbers of fatally and seriously injured VRU (Fig. 2). Similar trends can be observed in most of the seven InDeV countries, with some exceptions:

- Denmark, where in 2013 (compared to 2012) the number of fatally injured VRU increased, while the number of seriously injured decreased (Fig. 3);

- The Netherlands, where from 2009 to 2013 the number of fatally injured VRU decreases a little but the number of seriously injured has a huge drop for 3 years and then an increase (Fig. 4);

- Spain, where in 2011 (compared to 2010) we see a drop in the number of fatally injured VRU but an increase in the number of seriously injured (Fig. 5).

By contrast, the data for Poland (Fig. 6) show a consistent decreasing trend in both fatalities and seriously injured. It is not known what are the reasons for these differences. Possible reasons are unusual weather conditions, safety improvement measures but also underreporting or misreporting of injury severity. These could also be due to changes in the procedures of gathering and processing of accident data.

In order to compare the safety situation in countries of different size, fatality and injury rates can be calculated. These are expressed as the number of fatalities or injuries per million population per year. Comparison of fatality data for the $7 \mathrm{InDeV}$ countries shows that (Fig. 7):

- Poland has the highest fatality rate for pedestrians with an extremely high value of 33.7 fatally injured/year/million population ${ }^{7}$;

- The highest fatality rates for cyclists occur in the Netherlands (8.3) and Poland (7.9);

- The highest moped riders' fatality rates occur in the Netherlands (2.4) and Denmark (2.3);

- The highest fatality rate for motorcyclists occurs in Belgium (10).

\footnotetext{
${ }^{7}$ The dramatic situation of pedestrians in Poland has been known and examined in many studies e.g.: [13], [20].
} 

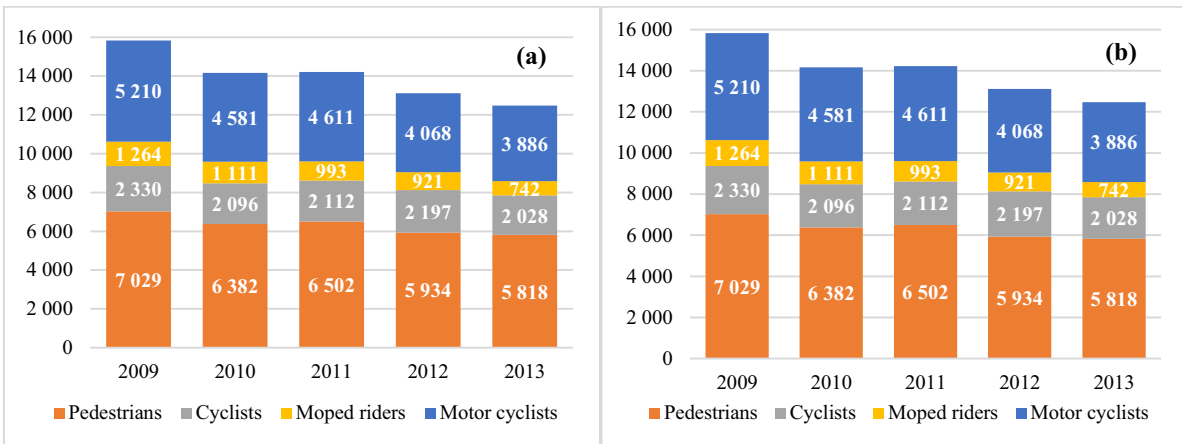

Fig. 2. EU28 countries - (a) fatally and (b) seriously injured VRU

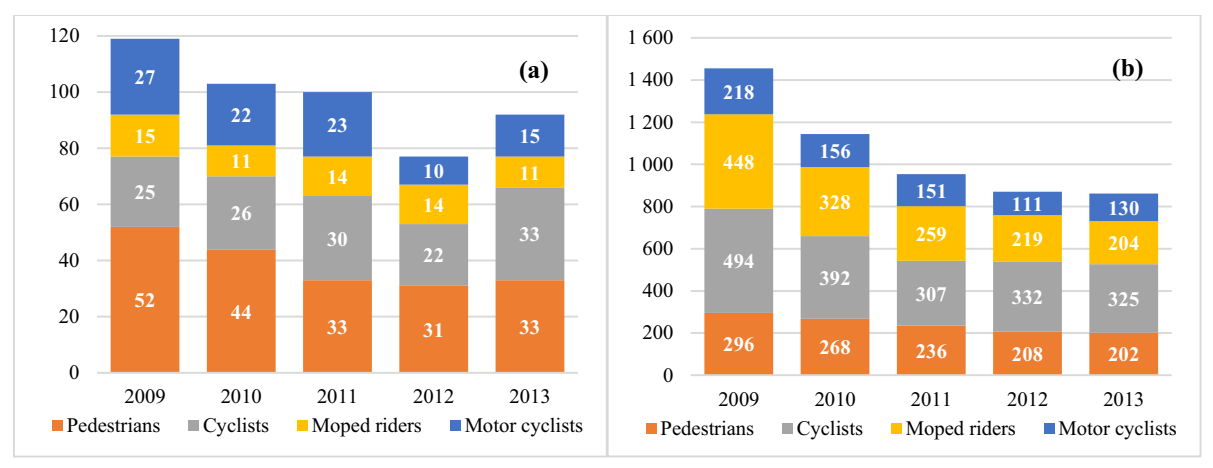

Fig. 3. Denmark - (a) fatally and (b) seriously injured VRU

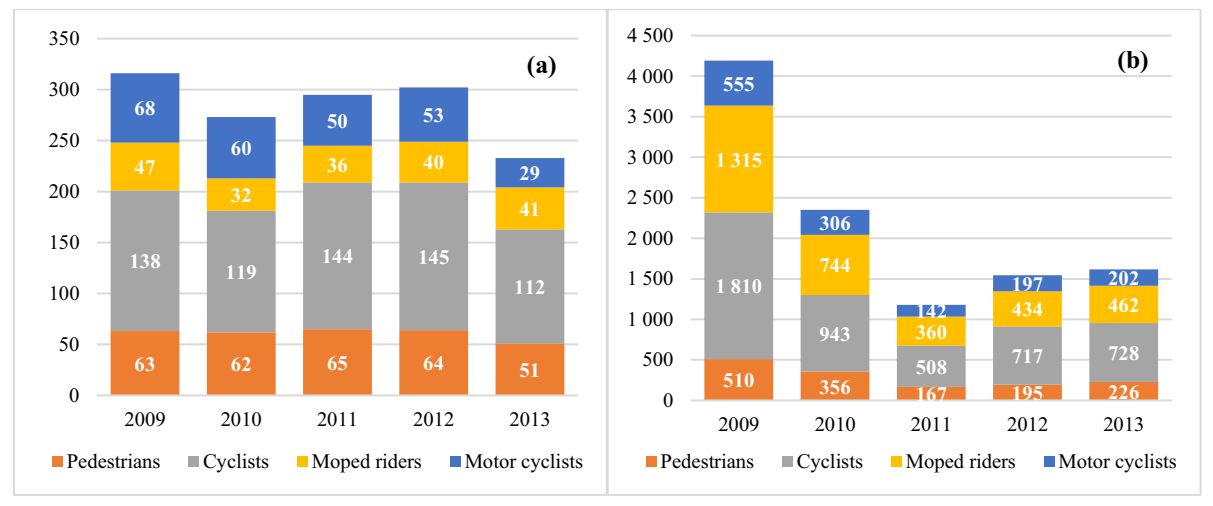

Fig. 4. The Netherlands - (a) fatally and (b) seriously injured VRU 


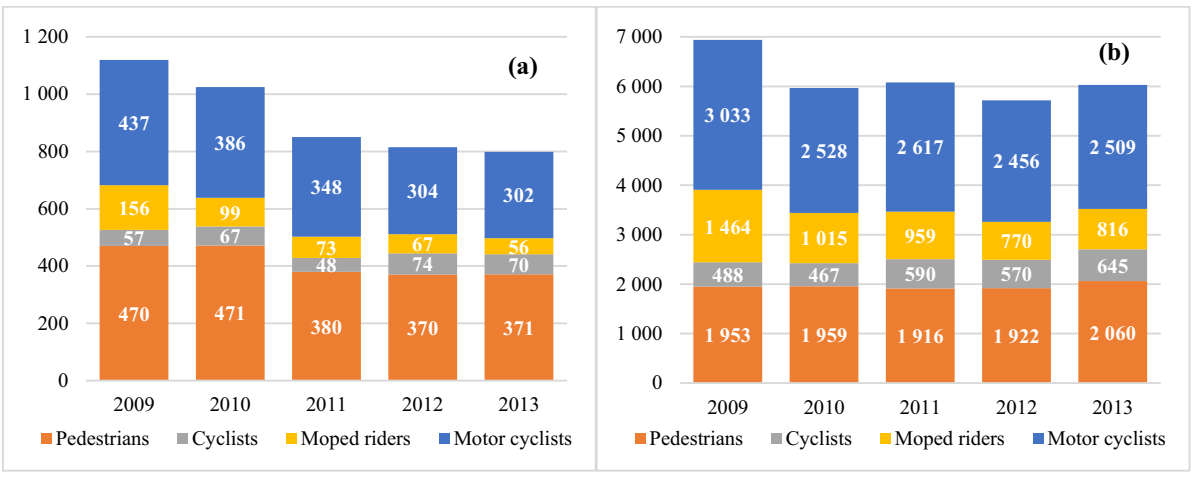

Fig. 5. Spain - (a) fatally and (b) seriously injured VRU

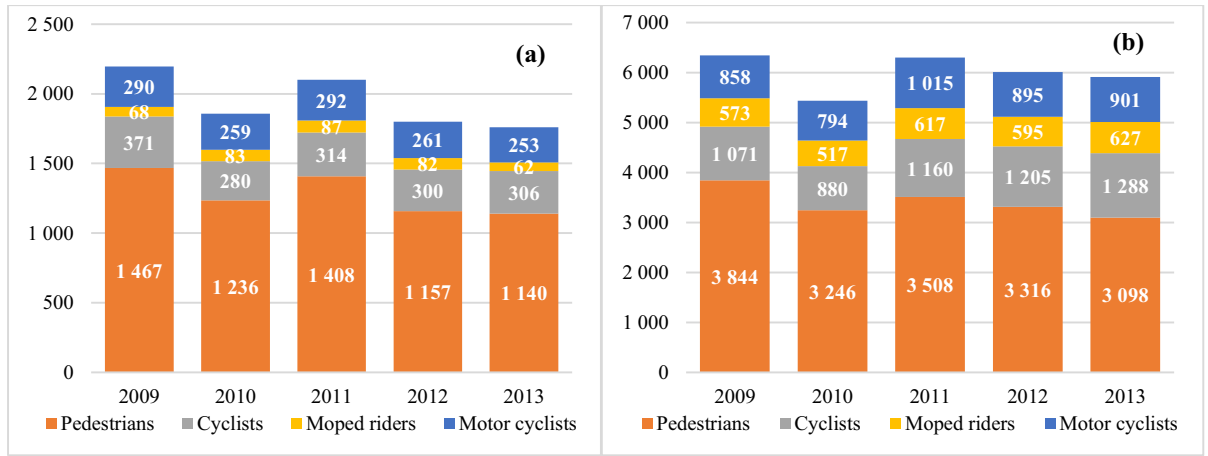

Fig. 6. Poland - (a) fatally and (b) seriously injured VRU

Comparison of serious injury data for the $7 \mathrm{InDeV}$ countries shows that (Fig. 8):

- The two highest serious injury rates for pedestrians occur in Germany (97 injuries/year/million population) and in Poland (89 injuries/year/million population);

- Germany has the highest serious injury rate for cyclists with an extremely high value (166);

- The highest and extremely high serious injury rate for motorcyclists also occurs in Germany (113).

- The highest serious injury rate for moped riders occurs in Denmark (52).

For some countries there is a large disproportion between fatality and serious injury rates. Based on fatality rates (Fig. 7), the safety situation of pedestrians and cyclists is the worst in Poland (among the 7 countries analysed). But looking at the serious injury rates (Fig. 8) it is Germany where the worst situation occurs for pedestrians, cyclists and motorcyclists. 


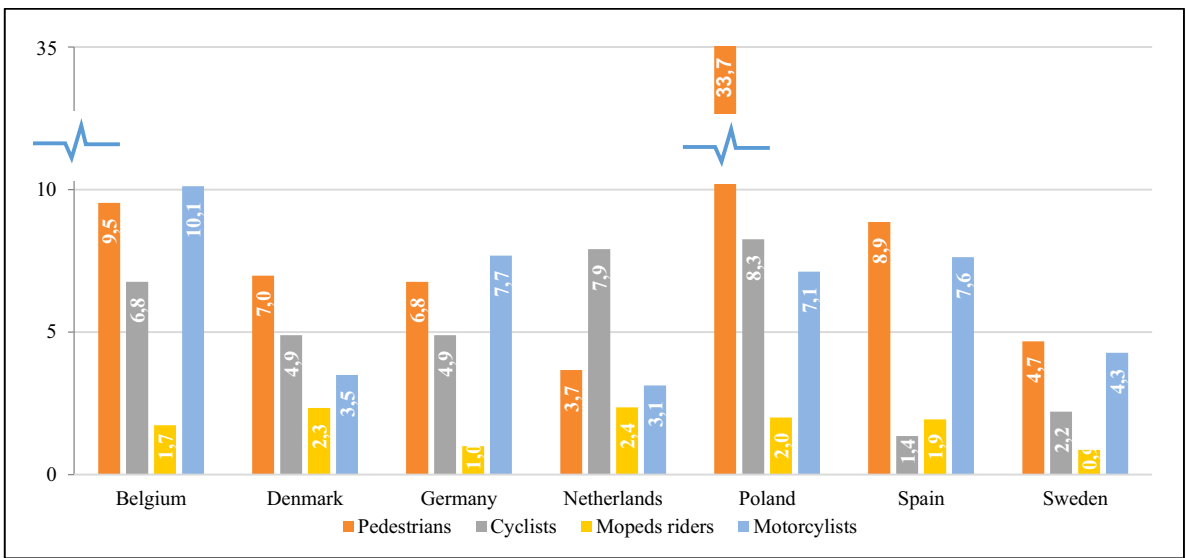

Fig. 7. VRU fatality rates (killed/million population/year) in $7 \mathrm{InDeV}$ countries, 2009-2013

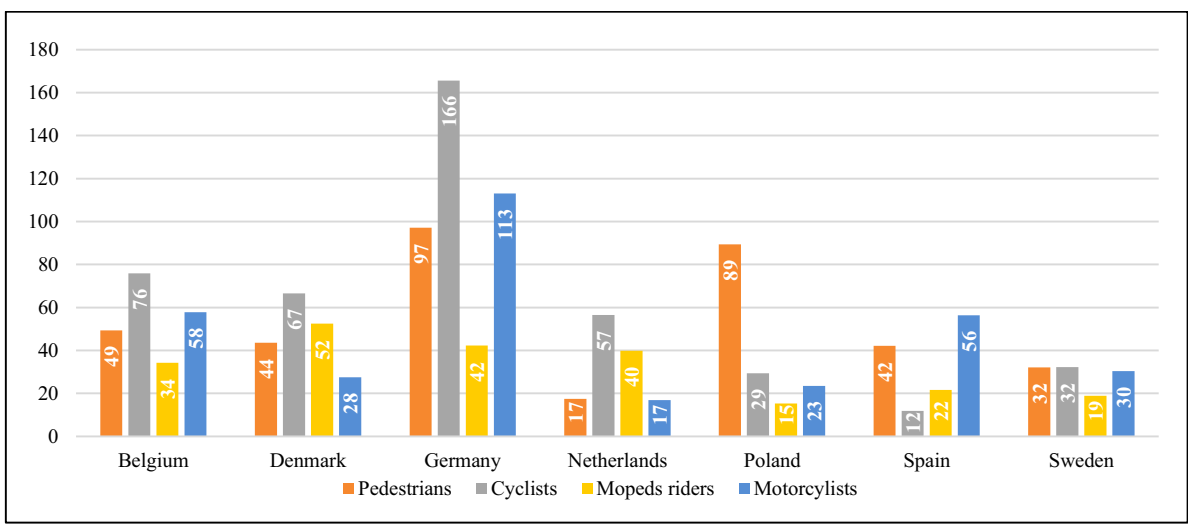

Fig. 8. VRU serious injury rates (seriously injured/mln population/year) in 2009-2013

Another way to look at these differences is to calculate the ratios of seriously injured and slightly injured to fatally injured. Table 1 presents these ratios for the 7 countries as well as for EU28. In Poland, these ratios both for seriously and slightly injured are much lower than the European average which could mean two things: either very high accident severity (a high proportion of accident victims are killed) or serious underreporting of injury accidents. The opposite is true for Germany - the ratios in Table 1 are much higher than European average. A possible explanation is that the accident reporting is accurate and even very slight injuries are reported. 
Table 1. Differences in ratio of seriously injured and slightly injured to fatally injured, 2009-2013

\begin{tabular}{|c|c|c|c|c|c|c|c|c|c|c|c|c|}
\hline \multirow[t]{2}{*}{ Country } & \multicolumn{4}{|c|}{ Fatally injured } & \multicolumn{4}{|c|}{ Seriously injured/fatally injured } & \multicolumn{4}{|c|}{ Slightly injured/fatally injured } \\
\hline & 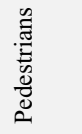 & $\begin{array}{l}\frac{n}{0} \\
\frac{02}{0} \\
0 \\
0\end{array}$ & 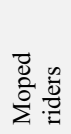 & 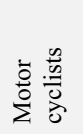 & 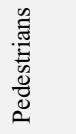 & $\begin{array}{l}\frac{n}{0} \\
\frac{2}{0} \\
0 \\
0\end{array}$ & 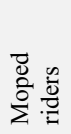 & 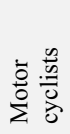 & 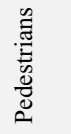 & $\begin{array}{l}\frac{0}{0} \\
\frac{3}{0} \\
0 \\
0\end{array}$ & 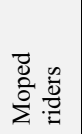 & 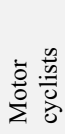 \\
\hline Belgium & 52 & 371 & 95 & 555 & 5 & 11 & 20 & 6 & 31 & 83 & 197 & 25 \\
\hline Germa & 2769 & 2002 & 409 & 3147 & 14 & 34 & 42 & 15 & 42 & 147 & 173 & 30 \\
\hline Denma & 15 & 13 & 65 & 97 & 6 & 14 & 22 & 8 & 5 & 15 & 18 & 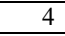 \\
\hline Spain & 2063 & 31 & 451 & 1777 & 5 & 9 & 11 & 7 & 22 & 59 & 92 & 46 \\
\hline Netherlands & 305 & 658 & 196 & 260 & 3 & 7 & 17 & 5 & 6 & 13 & 41 & 7 \\
\hline Poland & 6408 & 1571 & 382 & 1355 & 3 & 4 & 8 & 3 & 5 & 9 & 19 & 5 \\
\hline Sweder & 220 & 104 & 41 & 201 & 7 & 15 & 22 & 1 & 27 & 80 & 129 & 18 \\
\hline EU28 & 31667 & 10764 & 5031 & 22356 & 5 & 12 & 14 & 7 & 16 & 51 & 51 & 18 \\
\hline
\end{tabular}

Another big problem in comparing the road safety situation in different countries is the missing data. For example, in the CARE database, for accidents with VRU victims, there is no information about:

- Junction control type: Germany (100\% unknown), Sweden (94\%), Poland (82\%), Netherlands (81\%), Denmark (70\%), Spain (54\%);

- Weather conditions: Germany (47\% unknown), Sweden (43\%), Poland (19\%);

- Light conditions: Netherlands (56\% Unknown);

- Speed limits: Spain (100\% unknown), Germany (60\%), Sweden (18\%).

The main challenges associated with dataset analysis and with the identification of the most dangerous locations for VRU safety in the EU are the differences in data quality between countries and the lack of detailed information about accidents involving VRU. Large differences in numbers of accidents, accident rates and lack of some categories of variables in CARE are the reason that the results of this analysis are questionable. Therefore, identifying the road safety problems and meaningful comparative analysis is very often impossible.

In order to clarify these problems with CARE data for different countries a questionnaire survey was conducted in the $7 \mathrm{InDeV}$ countries.

\section{INDEV QUESTIONNAIRE SURVEY ON DATA QUALITY}

One of the aims of the project was to assess the quality and availability of accident and injury data with relevance to VRU safety problems. The questionnaire survey on accident data quality was designed to examine accident data collection procedures and database creation and the methods of 
their verification in each partner country as well as to identify the gaps in the currently used methodology and data.

The questionnaire was sent to all $\mathrm{InDeV}$ partners in Europe. The key issues taken into account in the questionnaire-based survey included data comparability among the countries involved in the project and data accuracy and credibility. The complete questionnaire on accident data quality is provided in appendix to the project report [21].

Table 2 and Table 3 present and summarise the results of the survey. Below the tables comments and explanations related to individual questions are presented, country by country.

Table 2. Accident data definitions and collection procedures

\begin{tabular}{|c|c|c|c|c|c|c|c|}
\hline ROAD ACCIDENT DATA COLLECTION & $\underset{\Xi}{\Xi}$ & 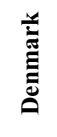 & & 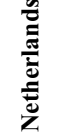 & 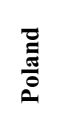 & 占 & ప \\
\hline \multicolumn{8}{|l|}{ Applicability of CARE definition to: } \\
\hline - Road accident/injury accident & Yes & Yes & Yes & No & Yes & Yes & No \\
\hline - Killed/fatally injured & Yes & Yes & Yes & Yes & Yes & Yes & No \\
\hline - Injured & Yes & No & Yes & No & No & Yes & No \\
\hline - Seriously injured & Yes & No & Yes & No & No & Yes & No \\
\hline - Slightly injured & Yes & No & Yes & No & No & Yes & No \\
\hline - Not injured & Yes & Yes & Yes & Yes & Yes & No & Yes \\
\hline \multicolumn{8}{|l|}{ Data collection procedure } \\
\hline From paper form to computer database & Yes & Yes & Yes & Yes & Yes & Yes & Yes \\
\hline \multicolumn{8}{|l|}{ Source of information about victim's injuries } \\
\hline - $\quad$ ambulance & $\mathrm{X}$ & $\mathrm{X}$ & $\mathrm{X}$ & & & $\mathrm{X}$ & \\
\hline - emergency room/admissions & & $\mathrm{X}$ & $\mathrm{X}$ & & $\mathrm{X}$ & & $\mathrm{X}$ \\
\hline - other hospital departments & & & $\mathrm{X}$ & & & & $\mathrm{X}$ \\
\hline - road users involved in accidents & & & $\mathrm{X}$ & $\mathrm{X}$ & & $\mathrm{X}$ & \\
\hline - other sources & $\mathrm{X}$ & $\mathrm{X}$ & & & & & \\
\hline \multicolumn{8}{|l|}{ Verification of information on injuries } \\
\hline Verification of information about victim's injuries & Yes & Yes & Yes & Yes & Yes & No & Yes \\
\hline \multicolumn{8}{|l|}{ Classification of injury severity } \\
\hline Classification of injury severity by the police & Yes & Yes & Yes & Yes & Yes & Yes & No \\
\hline - based on doctor's opinion & & $\mathrm{X}$ & & & $\mathrm{X}$ & $\mathrm{X}$ & \\
\hline - using MAIS3+ classification & & & & & & & \\
\hline - using AIS 2005 classification & & & & $\mathrm{X}$ & & & \\
\hline - other & $\mathrm{X}$ & $\mathrm{X}$ & $\mathrm{X}$ & & $\mathrm{X}$ & & \\
\hline
\end{tabular}

In Belgium, police officers assess the injuries/the severity of injuries based on the length of hospital stay. If the injured person stays longer than $24 \mathrm{~h}$ in hospital they are treated as seriously injured. There are independent research bureaus that compare police data with hospital data in order to assess the MAIS3+ (Maximum Abbreviated Injury Scale 3 or more) injury level for victims. 
Table 3. Quality of road accident data

\begin{tabular}{|c|c|c|c|c|c|c|c|}
\hline QUALITY OF ROAD ACCIDENT DATA & 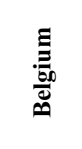 & 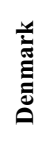 & 胥 & 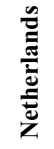 & $\begin{array}{l}\bar{\Xi} \\
\frac{\tilde{J}}{0} \\
\stackrel{0}{0}\end{array}$ & जี & 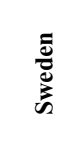 \\
\hline \multicolumn{8}{|l|}{ Data quality control } \\
\hline Carrying out of data quality control & Yes & Yes & Yes & Yes & Yes & Yes & Yes \\
\hline - while filling out the paper form & $\begin{array}{c}\text { Not } \\
\text { known }\end{array}$ & & No & No & $\begin{array}{c}\text { Not } \\
\text { known }\end{array}$ & Yes & $\begin{array}{c}\text { Not } \\
\text { known }\end{array}$ \\
\hline - while transferring to the computer & Yes & & Yes & No & Yes & & $\begin{array}{c}\text { Not } \\
\text { known }\end{array}$ \\
\hline - after transferring to the computer database & Yes & Yes & Yes & Yes & Yes & & Yes \\
\hline \multicolumn{8}{|l|}{ Methods of police accident database quality control } \\
\hline - cross checking consistency of information & No & Yes & Yes & No & Yes & Yes & No \\
\hline - comparing with other data & No & No & No & Yes & No & No & No \\
\hline - other & Yes & No & Yes & Yes & No & No & Yes \\
\hline \multicolumn{8}{|l|}{ Availability of underreporting studies } \\
\hline $\begin{array}{l}\text { Availability of the studies/reports/analyses about underreporting of } \\
\text { accidents/victims }\end{array}$ & Yes & Yes & Yes & Yes & Yes & No & Yes \\
\hline - including those relating to VRU accidents & No & Yes & Yes & Yes & No & No & Yes \\
\hline \multicolumn{8}{|l|}{ Comparison of data } \\
\hline Use of other databases to compare with the police acci & Yes & Yes & No & Yes & No & Yes & Yes \\
\hline
\end{tabular}

In Denmark, the definition of an injured person describes a person with injuries for which medical treatment or hospitalization is normally required. Persons with lesser wounds, minor cuts and bruises are not recorded as injured. The distinction between those seriously and slightly injured is based on the type of injury. The police officers assess the injuries/the severity of injuries based on an on-site assessment and on the doctor's opinion. The Danish national database is not suitable for analysis of VRU safety in terms of data completeness due to significant underreporting.

In Germany, the police do not asses injuries but use the information from the medical services or the road users involved in accidents. Injury severity is assessed based on the CARE definition. The following methods are used as part of the quality control of the computer database: cross-checking of information consistency and completeness and plausibility checks.

In the Netherlands, road accident/injury accident is an incident on a public road that is traffic-related, inflicts damage to objects or injury to persons and involves at least one moving vehicle. "Injured" is a person that was physically harmed in a traffic accident while "seriously injured" is the road user who was hospitalized and treated in a Dutch hospital and has an AIS (Abbreviated Injury Scale) score of 2 or higher. The accident database is complete for about $90 \%$ of accidents with fatally injured persons. In the case of lighter injuries, the database is less complete. The actual number of victims is estimated by way of combining different databases. The Dutch police do not register all traffic accidents and victims. The alternative registries are not complete either. Registration by the police 
further deteriorated after the introduction of some new systems in 2009. Registration has been improving again since 2014.

In Poland, a seriously injured person is one who suffered a severe disability, a serious incurable disease or a long-term life-threatening illness, a permanent mental disease, complete/significant permanent incapacity for work or substantial permanent body disfigurement or deformation. This definition also includes persons who suffered other injuries that caused impaired organ function or derangement of health for a period of more than 7 days. A slightly injured person is one who suffered a health impairment, other than in the case of serious injury, that caused impaired organ function or derangement of health for a period of no more than 7 days, as diagnosed by the physician. Police officers assess the severity of injuries based on the doctor's opinion, their own opinion and experience as well as judicial documentation. Physicians assess injuries using the ICD-10 (International Classification of Diseases) classification.

In Spain, "not injured" category does not exist. The police gather information about victims' injuries based on the information from the ambulance (rescue team) or from the road users involved in the accidents but the police never verify this information. The severity of injuries is assessed by the police based on the doctor's opinion. The information is cross-checked for consistency.

In Sweden, both police and hospital records end up in the STRADA database. Injury severity is defined based on the hospital register. The seriously injured is a person with an ISS (Injury Severity Score) score greater than 9, but there is also a group of "moderately injured" with an ISS score of 4-8. Slightly injured are those with an ISS score of 1-3. Follow-ups are made and the database is updated up to 1 year after the accident date.

The information obtained through the InDeV questionnaire survey can be summarised as follows:

- Even in the case of the fundamental definition of "road accident/injury accident", the definitions used by some countries (e.g. the Netherlands and Sweden) differ slightly from the standard used in the CARE database.

- Data on fatalities are quite comparable between the $\mathrm{InDeV}$ partner countries. According to the CARE glossary, a fatally injured person is one who dies on the spot or within 30 days of the accident. However, the CARE definitions of injury severity are applied only in Belgium, Germany and Spain.

- In all of the InDeV partner countries, accident data are collected on a paper form and transferred to a computer database. The information on crash severity is gathered from the ambulance (Belgium, Denmark, Germany, Spain), emergency room (Denmark, Germany, Poland, Sweden), other hospital departments (Germany and Sweden) and the road users involved in the accidents 
(Germany, the Netherlands, Spain). In the case of fatalities, the information about the accident is provided to the police by the judicial services in Belgium.

- Apart from Spain, the information about victims' injuries is verified on the basis of information from hospital departments. The waiting time for the police check of the information on crash severity is not specified in Belgium. In Denmark, the verification is performed once a year by way of comparing the registry of injured road users with the registry of deceased persons in the case of road fatalities. In Germany, it depends on the necessity for police investigation procedures. In Poland, the information about victims is verified twice: on the day of the accident and 30 days after the accident. The verification of data in Sweden is performed automatically via the STRADA database, which links the police database with hospital registries.

- It is acknowledged that there is a large data gap in the Netherlands because the police do not register all traffic accidents, especially injuries. The actual number of victims is estimated by combining different databases.

- Most countries have various classification criteria of injury severity such as the doctor's opinion (Denmark, Poland, Spain) and the length of hospital stay (Belgium). In Germany, the classification is based on CARE definitions. The AIS classification is used in the Netherlands and Sweden. None of the countries stated that they applied the MAIS3+ scale which is now recommended by the EC.

- In almost all InDeV partner countries, data quality control is carried out after data is transferred to a computer database; in Spain it is performed while filling out the paper form. Cross-checking for consistency of information is used in Denmark, Germany (also completeness and plausibility checks), Spain and Sweden (between police records and hospital records).

- Studies on the underreporting of road accidents have been performed and are available in most InDeV partner countries (except Spain); those associated with VRU accidents: in Denmark, Germany, the Netherlands and Sweden.

- The police accident databases are compared with hospital databases in Belgium (by research bureaus), Denmark (as part of research projects), the Netherlands and Sweden (the STRADA system) and with the databases maintained by municipalities in Spain.

- In all countries except for the Netherlands, national databases are suitable for VRU safety analyses. The reliability of data was confirmed by almost all countries. The data on VRU victims is not complete in Belgium and Poland. In the Netherlands, there is a large gap in accident data. 


\section{Conclusions}

The literature review presented in this paper and the responses to the $\mathrm{InDeV}$ survey on accident data quality allow us to formulate the following general conclusions:

- Despite efforts to harmonise the definitions of injury accidents and their severity at the European and global levels, differences exist both in the definitions and their interpretation.

- Even in the case of the fundamental definition of "road accident/injury accident", the definitions used by some countries differ slightly from the CARE standard. Data on fatalities are quite comparable between the $\mathrm{InDeV}$ countries: the 30-day road fatality definition is used. CARE definitions of injury severity are applied in only 3 out of 7 countries.

- There are also considerable differences between countries in terms of accident data collection and data verification procedures resulting in varying levels of underreporting of the various accident categories. A new initiative is required to harmonise the data collection systems and procedures.

- The European CARE database was developed with a comprehensive structure and scope of information as defined in the CADaS glossary. The great advantage of using CARE for safety research is that it is a disaggregate database. However, the guidelines on the scope of data to be provided are not followed by all countries. For example, information on the accident type and vehicle manoeuvres are generally not provided. The possibilities of safety analysis would be greatly improved if the guidelines were followed by all countries.

Several recommendations for improving VRU safety assessment can be put forward:

- Single pedestrian accidents constitute a sizeable part of injury accidents but are not included in databases based on police reports. It is recommended to include this additional category in VRU safety assessment studies as well as in the economic calculations of total accident costs.

- The definition of personal injury is not clear, consistent or harmonised between EU-countries and there is a "grey area" between "slight injury" and "property damage only" accidents. Since the occurrence of an "injury" is one of the preconditions to classify a collision as an accident, a clear definition of injury is needed.

- To improve the quality of accident data recorded by the police, these should be complemented with data registered by hospitals. Guidelines for the integration of police and medical data based on best practices (e.g. the STRADA system in Sweden) would be very useful. 


\section{ACKNOWLEDGEMENT}

Research reported in this paper is sponsored by the European Commission as part of project $\mathrm{InDeV}$ within Horizon 2020 Programme under grant agreement No 635895. This publication reflects only the authors' view. Responsibility for the information and views expressed therein lies entirely with the authors. The authors would like to thank all the project InDeV partners (Lund University Sweden; Ålborg University - Denmark; Hasselt University - Belgium; BASt - Germany; TNO - the Netherlands; INTRA - Spain) for their input.

\section{REFERENCES}

1. $\quad$ L. T. Aarts et al., "Study on Serious Road Traffic Injuries in the EU", 2016.

2. J. Alsop and J. Langley, "Under-reporting of motor vehicle traffic crash victims in New Zealand", Accid. Anal. Prev., vol. 33, no. 3, pp. 353-359, 2001.

3. E. Amoros, J. L. Martin, and B. Laumon, "Under-reporting of road crash casualties in France", Accid. Anal. Prev., vol. 38 , no. 4 , pp. $627-635,2006$.

4. K. Austin, "The identification of mistakes in road accident records: Part 2, casualty variables", Accid. Anal. Prev., vol. 27 , no. 2 , pp. $277-282,1995$.

5. M. Chisvert, E. López-de-Cózar, and M. L. Ballestar, "Quality and representativity of the traffic accident data in urban areas. State of the Art", 2007.

6. Y. Chung and I. Chang, "How accurate is accident data in road safety research? An application of vehicle black box data regarding pedestrian-to-taxi accidents in Korea.", Accid. Anal. Prev., vol. 84, pp. 1-8, 2015.

7. F. Conche and M. Tight, "Use of CCTV to determine road accident factors in urban areas", Accid. Anal. Prev., vol. 38, no. 6, pp. 1197-1207, 2006.

8. Directorate-General for Mobility and Transport, "CARE Database. CaDaS Common acccident Data Set", no. February, 2013.

9. EC, "Commision staff working document on the implementation of objective 6 of the European Commission's policy orientations on road safety 2011-2020 - First milestone towards an injury strategy", 2013.

10. R. Elvik, A. Høje, T. Vaa, and M. Sørensen, "The Handbook of Road Safety Measures", Second edi.,2009.

11. R. Elvik and A. Mysen, "Incomplete accident reporting: meta-analysis of studies made in 13 countries", Transp. Res. Rec. J. Transp. Res. Board, no. 1665, pp. 133-140, 1999.

12. J. Hill, M. Aldah, R. Talbot, G. Giustiniani, H. Fagerlind, and M. Jänsch, "Road Safety Data, Collection, Transfer and Analysis", Final Report, Deliverable 2.5 of the EC FP7 project DaCoTA, 2012.

13. K. Jamroz, W. Kustra, M. Budzyński, and J. Żukowska, "Pedestrian protection, speed enforcement and road network structure the key action for implementing Poland's Vision Zero", Transp. Res. Procedia, vol. 14, pp. 3905-3914, 2016.

14. C. Juhra et al., "Bicycle accidents - Do we only see the tip of the iceberg?: A prospective multi-centre study in a large German city combining medical and police data", Injury, vol. 43, no. 12, pp. 2026-2034, 2012

15. J. D. Langley, "Missing cyclists", Inj. Prev., vol. 9, no. 4, pp. 376-379, 2003.

16. B. P. Y. Loo, "Validating crash locations for quantitative spatial analysis: A GIS-based approach", Accid. Anal. Prev., vol. 38, no. 5, pp. 879-886, 2006.

17. B. P. Y. Loo and K. L. Tsui, "Bicycle crash casualties in a highly motorized city", Accid. Anal. Prev., vol. 42, no. 6, pp. 1902-1907, 2010.

18. J. Luoma and M. Sivak, "Characteristics and availability of fatal road-crash databases in 20 countries worldwide", J. Safety Res., vol. 38, no. 3, pp. 323-327, 2007.

19. M. Muller and S. Haustein, "Factors contributing to young moped rider accidents in Denmark", Accid. Anal. Prev., vol. 87, pp. 1-7, 2016.

20. P. Olszewski, P. Szagała, M. Wolański, and A. Zielińska, "Pedestrian fatality risk in accidents at unsignalized zebra crosswalks in Poland", Accid. Anal. Prev., vol. 84, pp. 83-91, 2015.

21. P. Olszewski et al., "Review of current study methods for VRU safety", Deliverable 2.1 Project Report - InDeV, 2016, http://www.indev-project.eu/InDeV/EN/Documents/pdf/2-1-1.pdf? blob=publicationFile\&v=1. 
22. P. Schepers et al., "An international review of the frequency of single-bicycle crashes (SBCs) and their relation to bicycle modal share.", Inj. Prev., pp. 1-6, 2014.

23. D. A. M. Twisk and M. Reurings, "An epidemiological study of the risk of cycling in the dark: The role of visual perception, conspicuity and alcohol use", Accid. Anal. Prev., vol. 60, pp. 134-140, 2013.

24. WHO, "Data systems: A Road Safety Manual for Decision-Makers and Practitioners", pp. 1-164, 2010.

25. WHO, "Global status report on road safety 2013: supporting a decade of action", 2013.

26. G. Yannis et al., "D.1.14 CADaS - The Common Accident Data Set", SafetyNet Deliverable, 2008.

\section{LIST OF FIGURES AND TABLES:}

Fig. 1. Road user collision matrix

Rys. 1. Macierz kolizji uczestników ruchu

Fig. 2. EU28 countries - (a) fatally and (b) seriously injured VRU

Rys. 2. Kraje UE28 - (a) zabici oraz (b) ciężko ranni niechronieni uczestnicy ruchu

Fig. 3. Denmark - (a) fatally and (b) seriously injured VRU

Rys. 3. Dania - (a) zabici oraz (b) ciężko ranni niechronieni uczestnicy ruchu

Fig. 4. The Netherlands - (a) fatally and (b) seriously injured VRU

Rys. 4. Holandia - (a) zabici oraz (b) ciężko ranni niechronieni uczestnicy ruchu

Fig. 5. Spain - (a) fatally and (b) seriously injured VRU

Rys. 5. Hiszpania - (a) zabici oraz (b) ciężko ranni niechronieni uczestnicy ruchu

Fig. 6. Poland - (a) fatally and (b) seriously injured VRU

Rys. 6. Polska - (a) zabici oraz (b) ciężko ranni niechronieni uczestnicy ruchu

Fig. 7. VRU fatality rates (killed/million population/year) in $7 \mathrm{InDeV}$ countries 2009-2013

Rys. 7. Wskaźniki zagrożenia niechronionych uczestników ruchu (zabici/milion mk./rok), 2009-2013

Fig. 8. VRU serious injury rates (seriously injured/mln population/year) in 2009-2013

Rys. 8. Wskaźniki zagrożenia niechronionych uczestników ruchu (ciężko ranni/milion mk./rok), 20092013

Tab. 1. Differences in ratio of seriously injured and slightly injured to fatally injured, 2009-2013

Tab. 1. Różnice w stosunku liczby ciężko rannych i lekko rannych do liczby zabitych, 2009-2013

Tab. 2. Accident data definitions and collection procedures

Tab. 2. Definicje dotyczące wypadków i procedury zbierania danych

Tab. 3. Quality of road accident data

Tab. 3. Jakość danych o wypadkach drogowych 


\section{PROBLEMY Z OCENĄ BEZPIECZEŃSTWA NIECHRONIONYCH UCZESTNIKÓW RUCHU NA PODSTAWIE DANYCH O WYPADKACH DROGOWYCH}

Slowa kluczowe: bezpieczeństwo ruchu drogowego, niechronieni uczestnicy ruchu, dane o wypadkach drogowych, baza CARE, jakość danych

\section{STRESZCZENIE:}

Artykuł przedstawia częściowe wyniki projektu InDeV, którego celem jest pogłębiona analiza przyczyn wypadków z niechronionymi uczestnikami ruchu (NUR). W ramach projektu zbadano jakość i spójność danych o wypadkach drogowych gromadzonych w krajach UE na podstawie raportów policyjnych. Problem zaniżonej liczby wypadków oraz niewłaściwego określania ich ciężkości dotyczy w szczególności NUR (pieszych, rowerzystów, motocyklistów i motorowerzystów). Wykonano analizy statystyczne oparte o dane pochodzące z europejskiej bazy o wypadkach drogowych CARE. Analiza ujawniła trudne do wytłumaczenia różnice pomiędzy krajami, zarówno w odniesieniu do trendów liczby wypadków, jak i wskaźników ofiar śmiertelnych i rannych.

Wśród krajów biorących udział w projekcie InDeV (Belgia, Dania, Hiszpania, Holandia, Niemcy, Polska i Szwecja) przeprowadzono badanie ankietowe, w którym pytano o zbieżność definicji dotyczących wypadków drogowych z terminami zalecanymi przez UE, o procedury zbierania danych, klasyfikację wypadków i kontrolę wprowadzania danych do krajowych baz a także studia nad problemem niedoszacowania liczby wypadków, wynikającym z braku zgłoszeń części zdarzeń drogowych. Badanie pozwoliło na zidentyfikowanie różnic w definicjach, a także w sprawozdawczości i procedurach kontroli danych. Pomimo wysiłków zmierzających do ujednolicenia definicji, w dalszym ciągu występują różnice, zarówno w ich brzmieniu jak i w interpretacjach. Nawet tak podstawowy termin jak „wypadek drogowy/wypadek z rannymi”, różni się w niektórych krajach od definicji przyjętej w CARE. Dane dotyczące wypadków śmiertelnych są porównywalne w krajach biorących udział w projekcie - stosowana jest definicja określająca ofiarę śmiertelną wypadku jako zabitego na miejscu lub zmarłego w ciągu 30 dni. Definicje CARE dotyczące ciężkości obrażeń są natomiast stosowane tylko w 3 z 7 krajów. Odmienne są również procedury zbierania i weryfikacji danych, co powoduje zróżnicowanie poziomu zaniżania liczby wypadków różnych kategorii. Istnieje potrzeba nowej inicjatywy europejskiej w celu zharmonizowania systemów i procedur zbierania danych o wypadkach drogowych.

Baza danych CARE posiada, zgodnie z modelem CADaS, kompleksową strukturę i zakres informacji. Jako baza danych zdezagregowana może być przydatna do badań nad bezpieczeństwem ruchu, jednak niektóre ważne informacje, np. na temat manewrów pojazdów uczestniczących w wypadku, nie są do niej na ogół dostarczane przez poszczególne kraje. W celu poprawy jakości oceny bezpieczeństwa NUR można sformułować następujące zalecenia:

- Wypadki z udziałem pojedynczych pieszych stanowią istotną część wypadków z rannymi, ale nie są zawarte w bazach danych utworzonych z wykorzystaniem raportów policyjnych. Zaleca się, aby uwzględnić tę dodatkową kategorię w badaniach oceny bezpieczeństwa NUR, a także w obliczeniach całkowitych kosztów wypadków.

- Definicja minimalnych obrażeń nie jest jasna i zharmonizowana wśród krajów UE. Istnieje „szara strefa” pomiędzy wypadkami z „lekko rannymi” a „wyłącznie zniszczeniem mienia”. Ponieważ wystąpienie „obrażeń” jest warunkiem niezbędnym do sklasyfikowania zdarzenia drogowego jako wypadku, konieczna jest ich jasna definicja.

- Dla poprawy jakości danych policyjnych, powinny one być uzupełniane o dane zarejestrowane przez szpitale. Bardzo użyteczne byłoby opracowanie wytycznych dotyczących integracji danych policyjnych i medycznych, wykorzystujących najlepsze praktyki (np. system STRADA w Szwecji). 